\title{
POR UMA CRÍTICA DA DIMENSÃO SACRIFICIAL DO NEOLIBERALISMO
}

\author{
For a Critique of the Sacrificial Dimension of Neoliberalism
}

Claudio Santana Pimentel ${ }^{1}$

\begin{abstract}
RESUMO: O presente artigo busca estabelecer diálogos entre Filosofia e Ciência da Religião, a partir da crítica ao neoliberalismo. Articulando as propostas críticas de Achille Mbembe e de Franz Hinkelammert, reveladoras da dimensão sacrificial do capitalismo neoliberal. Pretende-se contribuir para a compreensão da dinâmica filosófica que se encontra nos fundamentos religiosos dos grandes problemas contemporâneos. Desenvolve uma análise preliminar dos pressupostos sacrificiais presentes no discurso neoliberal em meio à pandemia do Covid-19.
\end{abstract}

PALAVRAS-CHAVE: Ciência da Religião; Filosofia; Capitalismo; Neoliberalismo; Sacrifício.

ABSTRACT: This article seeks to establish dialogues between Philosophy and Science of Religion, based on the criticism of neoliberalism. Articulating the critical proposals of Achille Mbembe and Franz Hinkelammert, revealing the sacrificial dimension of neoliberal capitalism. It is intended to contribute to the understanding of the philosophical dynamics that is found in the religious foundations of the great contemporary problems. It develops a preliminary analysis of the sacrificial assumptions present in the neoliberal discourse during the Covid-19 pandemic.

KEYWORDS: Science of Religion; Philosophy; Capitalism; Neoliberalism; Sacrifice.

O presente artigo busca, estabelecendo diálogos entre Filosofia e Ciência da Religião, contribuir para a reflexão sobre a dimensão sacrificial do neoliberalismo, considerado como o núcleo de sua proposta religiosa. Para tanto, articula a crítica de Achille Mbembe à "razão negra", a qual permitiu ao ocidente, ao desenvolver a imagem da África e do africano/negro como "outro" subalternizado, construir a sua própria imagem enquanto civilização, com a crítica desenvolvida por Franz Hinkelammert à dimensão sacrificial do capitalismo. Acreditamos assim contribuir para um estudo da dinâmica filosófica presente nos fundamentos religiosos dos grandes problemas contemporâneos. Em seguida,

\footnotetext{
${ }^{1}$ Doutor em ciências da religião pela Pontifícia Universidade Católica de São Paulo (PUC-SP) e pesquisador na mesma instituição. E-mail: pimentelclaudio@live.com
} 
desenvolvemos, a título de exemplo, uma análise inicial dos pressupostos sacrificiais sacrifício exigido sobretudo dos pobres e dos idosos - presente na racionalidade econômica neoliberal, diante da pandemia mundial do coronavírus, que coloca os interesses econômicos acima da preservação da vida.

Partimos do seguinte pressuposto: a experiência social contemporânea e, mais especificamente, a experiência religiosa, são marcadas pela lógica do capitalismo, sobretudo em seu atual estágio de desenvolvimento, neoliberal. Mais que isso, o próprio desenvolvimento do capitalismo neoliberal traz, em sua raiz, uma compreensão religiosa. É esse último aspecto que desejamos destacar, para isso desenvolvendo um diálogo com dois autores que, a partir de pontos de partida distintos, trazem à tona a fundamentação religiosa implícita no capitalismo neoliberal.

Achile Mbembe contribui para revelar a constituição da modernidade como um processo de conquista, em termos práticos e simbólicos, e que teve na escravidão africana moderna não somente o fundamento econômico da expansão e consolidação capitalista, mas que o neoliberalismo contemporâneo universaliza as concepções eurocentradas sobre a África e o africano, a primeira compreendida como inesgotável fonte de recursos, o segundo visto como força-de-trabalho a ser explorado até o seu completo esgotamento e descarte. No presente, essa lógica de uso e descarte atualiza-se por meio da dinâmica dos aplicativos, estendendo-se ao trabalhador contemporâneo, e a todas as pessoas que passam a serem consideradas como descartáveis, como desnecessárias.

Franz Hinkelammert apresenta a transformação da concepção sacrificial presente no cristianismo ocidental da Idade Média, que, na modernidade, assume os valores do capitalismo, sobretudo a noção de propriedade e o ideal de acumulação de riqueza como universais, admitindo e exigindo o sacrifício de todos que se oponham ou que sejam vistos como obstáculos a realização do seu ideal de progresso.

A atualidade das categorias de análise elaboradas por esses autores se manifesta na maneira como os interesses econômicos têm conduzido a reação global à expansão da Covid-19, pandemia que ainda se encontra em curso, portanto, qualquer avaliação aqui proposta a esse respeito somente tem caráter de reflexão preliminar.

No entanto, é possível afirmar que a Ciência da Religião, que se propõe como uma disciplina empírica, histórica e que tem como objeto de sua investigação as religiões concretas $^{2}$, pode enriquecer seu repertório analítico ao dialogar com as categorias

\footnotetext{
${ }^{2}$ Cf. USARSKI, Frank. Constituintes da Ciência da Religião. Cinco ensaios em prol de uma disciplina autônoma. São Paulo: Paulinas, 2006.
} 
analíticas de perfil filosófico e o repertório crítico elaborado por autores como Mbembe e Hinkelammert.

\section{Neoliberalismo e africanização do mundo}

Em Crítica da razão negra ${ }^{3}$, Mbembe descontrói o processo por meio do qual o Ocidente - em particular o francófono - estabeleceu a imagem da África e do africano/negro, relacionando-os ao escravizado. Em suas palavras, os termos África e negro "são o resultado de um longo processo histórico de produção de questões de raça"4.

Retomando o raciocínio de Said, ${ }^{5}$ que apresenta a construção da ideia de "Oriente" como um processo por meio do qual o ocidente cristão produziu a si mesmo, mediante a negação do outro, Mbembe expõe como os termos África/africano/negro foram desenvolvidos em meio ao processo colonial/imperialista, legitimando-o, não somente como uma construção de discurso, mas trazendo em si mesmo uma concepção de trabalho.

Trabalho que deve ser compreendido não somente como forma de produção de bens e serviços, mas, principalmente, como produção e divisão das formas de organização de mundo, que reservam à África a posição de eterna fonte de recursos, a serem permanentemente explorados, vilipendiados, e, quando não mais convenientes, descartados, entre os quais o africano/negro se apresenta como uma dentre tantas mercadorias a serem comercializadas, reduzido à condição de força-de-trabalho.

O substantivo $<<$ Negro $>>$ é depois o nome que se dá ao produto resultante do processo pelo qual as pessoas africanas são transformadas em mineral vivo de onde se extrai metal. Esta é a sua dupla dimensão metamórfica e económica. Se, sob a escravatura, África é o lugar privilegiado de extração deste mineral, a plantação no Novo Mundo, pelo contrário, é o lugar de sua fundição, e a Europa, o lugar da sua conversão em moeda. Esta passagem do homem-mineral ao homem-metal e do homemmetal ao homem-moeda é uma dimensão estruturante do primeiro capitalismo. ${ }^{6}$

Dessa trama, revela-se a inseparável relação em que os termos colonialismo/imperialismo ${ }^{7}$, escravidão, modernidade, capitalismo se articulam. O

\footnotetext{
${ }^{3}$ MBEMBE, Achille. Crítica da razão negra. 2. ed. Lisboa: Antígona, 2017.

${ }^{4}$ Ibid., p. 75.

5 SAID, Edward. W. Orientalismo. O Oriente como invenção do Ocidente. São Paulo: Companhia das Letras, 2007.

${ }^{6}$ MBEMBE, Achille. Op. Cit., p. 78. Destaque no original. (Manteve-se nas citações o texto em português de Portugal).

${ }^{7}$ O colonialismo e o imperialismo europeu tiveram papel fundamental na formação da compreensão moderna de "religião", e na formação da disciplina que hoje designamos como Ciência da Religião. A esse respeito cf. WIRTH, Lauri Emílio. Religião e epistemologias pós-coloniais. In: PASSOS, João Décio;
} 
processo de construção da modernidade se mostra incompreensível sem referência ao colonialismo e ao imperialismo, e evidentemente ao próprio racismo - um dos princípios estruturantes do colonialismo/imperialismo, consequentemente da própria modernidade, conforme análise desenvolvida por Wallerstein e Quijano ${ }^{8}$ em sua crítica do conceito de americanidade.

Orientalismo, americanidade, África/africano/negro, revelam-se aspectos complementares e indissociáveis daquilo que Wallerstein e Quijano nomearam como sistema-mundo, a partir do qual a Europa (posição à qual se acrescenta, mais tarde, os Estados Unidos) se estabelece como "centro" econômico e civilizacional da humanidade, relendo - ditando - a história a partir de sua própria perspectiva ${ }^{9}$, ou, como afirma Mignolo, se passa de "um o cenário da transformação de um mundo policêntrico e não capitalista antes de 1500 para uma ordem mundial monocêntrica e capitalista de 1500 a $2000 " 10$.

Como Wallerstein e Quijano demonstraram, a conquista e ocupação da América, com o estabelecimento de um modo de exploração colonial, marcado por características específicas de organização social, política e econômica em cada colônia americana, tendo em comum a subordinação aos interesses de uma metrópole europeia, contribuiu decisivamente para a formação da modernidade capitalista, tendo na etnicidade, compreendida como racialização do mundo, um de seus pilares; racialização que implica a cada raça ou grupo étnico - sem preocupar-me aqui em discutir as necessárias distinções entre os dois conceitos, raça e etnia - um lugar específico dentro das hierarquias desse sistema-mundo.

Por sua vez, Mbembe explicita o papel da escravidão como fundamento do capitalismo e como o neoliberalismo se revela um processo de africanização do trabalhador contemporâneo. Sem os recursos e a força-de-trabalho provida mediante a escravidão, o desenvolvimento da modernidade capitalista, tal como se deu, não seria compreensível, sobretudo, não seria possível.

USARSKI, Frank. (Orgs.). Compêndio de Ciência da Religião. São Paulo: Paulinas; Paulus: 2013, p. 129142.

${ }^{8}$ QUIJANO, Anibal; WALLERSTEIN, Immanuel. La americanidad como concepto, o América en el moderno sistema mundial. In: Revista Internacional de Ciencias Sociales, v. XLIV, n. 4, 1992, p. 583-594. ${ }^{9}$ DUSSEL, Enrique. 1492: o encobrimento do outro. (A origem do "mito da Modernidade"). Petrópolis, RJ: Vozes, 1993.

${ }^{10}$ MIGNOLO, Walter D. Colonialidade. O lado mais escuro da modernidade. Revista Brasileira de Ciências Sociais, v. 32, n. 94, junho/2017, p. 2. 
Em sua expressão contemporânea, a articulação do sistema-mundo capitalista se apresenta como neoliberalismo, que é assim definido pelo autor:

Por neoliberalismo entenda-se uma fase da história da Humanidade dominada pelas indústrias do silício e pelas tecnologias digitais. O neoliberalismo é a época ao longo do qual o tempo (curto) se presta a ser convertido em força reprodutiva da forma-dinheiro. Tendo o capital atingido o seu ponto de fuga máximo, desencadeou-se um movimento de escalada. O neoliberalismo baseia-se na visão segundo a qual $<<$ todos os acontecimentos e todas as situações do mundo (podem) deter um valor no mercado $>>$. Este movimento caracteriza-se também pela produção da indiferença, a codificação paranóica da vida social em normas, categorias e números, assim como por diversas operações de abstracção que pretendem racionalizar o mundo a partir de lógicas empresariais. ${ }^{11}$

O neoliberalismo, no presente, se apresenta como processo de "africanização" 12 do mundo. Como tal, se compreende a redução de todos aqueles que não possuem o controle do capital e de sua circulação, e a propriedade dos meios de produção e distribuição da riqueza a mera matéria, inerte, desumanizada, tal qual pedaço de carvão que uma vez consumido, descarta-se por ter se tornado inútil. Sobre o trabalhador neste atual momento, diz:

Já não há trabalhadores propriamente ditos. Já só existem nómadas do trabalho. Se, ontem, o drama do sujeito era ser explorado pelo capital, hoje, a tragédia da multidão é não poder mais ser explorada de todo, é ser objeto de humilhação numa humanidade supérflua, entregue ao abandono, que já nem é útil ao funcionamento do capital. [...]. Não sendo os automatismos psíquicos e os tecnológicos mais do que duas faces da mesma moeda, vai-se instalando a ficção de um novo ser humano, <<empresário de si mesmo $>$, plástico e convocado a reconfigura-se permanentemente em função dos artefactos que a época oferece. ${ }^{13}$

O paradigma do trabalho e do trabalhador contemporâneo concretiza-se por meio da dinâmica dos aplicativos, que invisibilizam relações, ocultando práticas de exploração laboral. Os aplicativos apresentam-se somente como veículos que aproximam prestadores de serviço a consumidores, usuários, como instrumentos que intermedeiam e facilitam negócios, numa práxis suposta e intencionalmente neutra, tendo como agravante o fato de que potencialmente todos podem se alternar, a depender do momento, entre o papel de prestadores de serviços e o de usuários.

Sujeito neuroeconómico absorvido pela dupla inquietação exclusiva da sua animalidade (a reprodução biológica da sua vida) e da sua coisificação (usufruir dos bens deste mundo), este homem-coisa, homemmáquina, homem-código e homem-fluxo, procura antes de mais nada regular a sua conduta em função de normas do mercado, sem hesitar em se auto-instrumentalizar e instrumentalizar outros para optimizar a sua quota-parte de felicidade. Condenado à aprendizagem para toda a vida, à flexibilidade, ao reino do curto prazo, abraça a sua condição de sujeito solúvel e descartável para responder à injunção que the é constantemente feita - tornar-se outro. ${ }^{14}$

\footnotetext{
${ }^{11}$ MBEMBE, Achille. Op. cit., p. 13.

${ }^{12}$ Ibid., p. 100.

${ }^{13}$ Ibid., p. 14.

${ }^{14}$ Ibid., p. 15.
} 
O sujeito neoliberal perambula imerso em um mundo marcado por uma permanente insegurança e precariedade. Sua vida se caracteriza por uma incerteza e instrumentalização, e, talvez a diferença entre o processo presente e aquele que caracterizou a exploração escravista da primeira modernidade se encontre no fato de que essa reificação não vem somente imposta por um agente externo, mas que passa a ser exercida pelos indivíduos sobre si mesmos e, como tal passa a ser desejada por esses mesmos indivíduos, que a assumem - por incrível que pareça - como autonomia, percebendo-a como "controle", não de outro sobre si, mas como assumir as rédeas da própria vida, enquanto afastam-se efetivamente desse ideal.

\section{Pressupostos do capitalismo sacrificial}

Hinkelammert propõe uma interpretação da sociedade liberal moderna compreendendo sua lógica interna como resultante do processo de secularização da dimensão sacrificial do cristianismo europeu medieval. Para a mentalidade daquele período, a ordem do mundo se estabelece a partir de um sacrifício fundante, que é a crucificação de Jesus Cristo, assassinado pelo Império Romano.

$\mathrm{Na}$ Modernidade, se mantem a concepção de sacrifício, mas se modifica a ideia sobre quem é o cordeiro sacrificial. Em leitura de John Locke, afirma que este seculariza o assassinato de Deus, colocando a espécie humana, ou, especificamente, a sociedade liberal-burguesa em seu lugar.

A lei divina, que em Locke se torna lei natural, é a lei da propriedade privada e da liberdade. Na verdade, liberdade e propriedade confundem-se, tornando-se uma coisa só. Aqueles que a ela se opõem são seus inimigos, assim como na Idade Média aqueles que não aceitavam a fé em Jesus Cristo (judeus, muçulmanos, cultuadores da natureza) eram inimigos.

Locke formula de forma clásica esta transformación del asesinato fundante del imperio cristiano en asesinato fundante del imperio liberal secularizado. Lo hace alrededor de lo que él llama la ley natural, que resume propiedad y libertad. Según Locke, ésta es la ley que Dios puso en el corazón del hombre. De este modo, la propiedad privada y la libertad derivada de ella, son la presencia de Dios en la tierra. ${ }^{15}$

\footnotetext{
${ }^{15}$ HINKELAMMERT, Franz. El asalto al poder mundial y la violencia sagrada del imperio. San José,
} Costa Rica: DEI, 2003, p. 225. 
Uma vez que a lei burguesa substitui, portanto, a Cristo - mantendo a concepção sacrificial do medievo - é o liberalismo-burguês que passa, na modernidade, a ser universal.

Como assinala Hinkelammert, no primeiro momento da expansão colonial europeia, tendo Portugal e Espanha à frente, é o cristianismo, em sua versão ocidental católica, que é levado e imposto aos povos subjugados. É preciso levar a religião cristã àqueles que não a conhecem.

A partir do momento em que o Reino Unido assume o protagonismo da conquista e expansão europeia, a justificativa da dominação se altera.

$\mathrm{Na}$ ordem liberal, não se trata mais de expandir as fronteiras do império cristão, mas sim de expandir as fronteiras do mercado. Não apenas povos e pessoas, como na conquista hispânica, mas a própria natureza se torna objeto da expansão do capital:

Con eso la agresión se hace efectivamente más agresiva. Se dirige tanto contra la población mundial, que es colonizada, como contra la naturaleza, convertida en objeto de conquista de parte de las ciencias empíricas, la tecnología y el mercado mundial. De la persecución de las brujas se pasa a la persecución de la naturaleza entera. ${ }^{16}$

As pretensões da globalização - de uma globalização liberal e burguesa - encontram suas raízes nessa concepção sacrificial. É preciso expandir o império liberal, é preciso garantir que a liberdade - esta compreendida como a garantia da propriedade privada seja levada a todos os cantos do mundo.

Não há alternativa, não há outra possibilidade para aqueles que se encontram fora da ordem burguesa: ou se submetem ou são sacrificados.

Y así como el imperio cristiano sale a crucificar universalmente a los crucificadores de Cristo, este imperio liberal sale a matar universalmente a todos quienes atropellan la ley burguesa y con ella a la humanidad y a Dios, quien puso en el corazón humano la ley burguesa de la libertad como propiedad privada. $^{17}$

A lógica da acumulação capitalista exige que a produção da riqueza seja transformada em obtenção de lucro, de maneira constante e contínua. Faz-se necessário alcançar novos mercados, inserir aqueles que não estão incluídos na dinâmica do capital.

Por isso, indivíduos, associações e regimes políticos que criticam ou se recusam a aceitar o modelo capitalista são considerados ameaças constantes e inimigos, tanto quanto os judeus, muçulmanos e adoradores da natureza medievais o eram em relação ao cristianismo ocidental.

${ }^{16}$ HINKELAMMERT, Franz. Op. cit., p. 226.
${ }^{17}$ Ibid., p. 227. 
A dimensão sacrificial do neoliberalismo explicitada por Hinkelammert, pode ser sintetizada na afirmação de que tudo pode ser sacrificado para que o sistema continue a funcionar; formas de governo que não se enquadram no modelo capitalista são inimigos, ameaças (por exemplo, Cuba); mecanismos de proteção aos trabalhadores, direitos trabalhistas, associações sindicais, também se constituem em inimigos, uma vez que se revelam ameaças à acumulação do capital e à expansão dos mercados, única razão de ser do sistema.

Nesse sentido, esboço, ainda que brevemente, uma aproximação entre a noção de capitalismo sacrificial e o processo de africanização do mundo, explicitado por Achille Mbembe em seu livro Crítica da razão negra.

A África e o africano/negro são termos elaborados a partir do Ocidente e de seus interesses, durante o processo de conquista colonial; a África é vista como uma única e inesgotável fonte de riquezas, sempre inerte, sempre passiva; riquezas e recursos naturais a serem permanentemente explorados, eternamente à disposição de quem queira usufruir delas.

O africano/negro, por sua vez, é força-de-trabalho a ser explorada, sua única razão de ser é sua submissão. Uma vez que essa submissão não mais é aceita, este deve ser controlado, assassinado e criminalizado, como aconteceu e ainda acontece nas sociedades que foram receptoras da mão-de-obra escravizada, caso - paradigmático - do Brasil. ${ }^{18}$

É interessante notar como, no decorrer da história da filosofia "ocidental", pensadores de diferentes épocas contribuíram para a hierarquização das relações que se estabeleceram no que, mais tarde, Wallerstein e Quijano chamariam de sistema-mundo.

Desde os pares matéria/forma e potência/ato, que estruturam a "física" de Aristóteles (que, recepcionada por filósofos e teólogos árabes e persas, adentra a Idade Média e chega, ainda que de baixo de toda sorte de crítica, à Modernidade): a matéria, a que corresponde a potência, está ali para ser desenvolvida, realizada, a forma/ato lhes são outorgados por um pensamento que o traz do caos ao cosmos: assim, a Europa assume a "missão" de transformar América/África/Ásia de mera potencialidade em ser, civilizando-as, assumindo tal "tarefa" como um dever, o "fardo do homem branco".

Considerado um dos fundadores da modernidade, Descartes, ao separar res cogitans e res extensa, vê nesta também a inércia a ser conduzida pelo trabalho do pensamento: o corpo é uma máquina, determinado por necessidades físicas e bioquímicas inescapáveis,

${ }^{18}$ Cf. BRITO, Ênio José da Costa. Leituras afro-brasileiras, v. 1. Ressignificações afrodiaspóricas diante da condição escravizada no Brasil. Jundiaí: Paco, 2018. 
enquanto o pensamento é a liberdade; considerando isso, o não-europeu, dentro do projeto civilizacional do Ocidente, reduz-se à ordem da necessidade, visto como corpo-trabalho, corpo-máquina, lenha para alimentar as fornalhas do "progresso".

O trabalhador da era neoliberal, mostra Mbembe, está aí para ser um "nômade do trabalho", acessado e descartado por meio de aplicativos. Uma vez cumprida sua tarefa retorna ao "nada" originário de onde saiu, tal como o escravizado do período colonial.

$\mathrm{Na}$ verdade, tais práticas se estendem para além das relações de trabalho, haja vista que a atenção às demandas laborais apresentadas mediante os aplicativos invadem todos os aspectos da vida dos trabalhadores, sem pedir licença, fazendo com que a separação público/privado, a dicotomia fundamental das sociedades modernas, se estreite na indistinção, cada vez mais gritante, entre a vida pessoal e a atividade profissional.

O neoliberalismo, conforme a análise de Hinkelammert, exige o sacrifício permanente da natureza e dos trabalhadores. Estes mesmos são naturalizados, ou seja, reduzidos a mera mão-de-obra, que, não mais sendo capaz de realizar sua função dentro do sistema, torna-se dispensável e descartável.

Assim, o "devir-negro-do-mundo"19, discutido por Mbembe, aproxima-se do capitalismo neoliberal em sua dimensão sacrificial, analisado por Hinkelammert. São visões que se articulam desde perspectivas distintas, se referindo à mesma realidade presente: uma ordem do mundo que exige, em nome de um progresso e de um desenvolvimento que beneficia elites globais que acumulam e controlam a maior parte da riqueza mundial, consumindo e descartando, em um processo contínuo e permanente; não mais o escravizado, como na modernidade nascente, mas o trabalhador-aplicativo da era neoliberal é triturado em uma máquina econômica que se tornou uma máquina de moer gente.

\section{A concepção sacrificial neoliberal em meio ao Covid-19}

Nesta seção, a pretensão é realizar, à luz dos elementos teóricos apresentados até aqui, uma reflexão preliminar sobre o discurso capitalista neoliberal, sobretudo na medida em que este afirma a necessidade da não restrição ao funcionamento das atividades

\footnotetext{
${ }^{19}$ MBEMBE, Achille. Op. cit., p. 9-22.
} 
econômicas, mesmo que a custo da perda de vidas humanas, em meio à pandemia do Covid- $19^{20}$, que se encontra ainda em curso enquanto este texto é escrito.

A pandemia do Covid-19 pode ser considerada a primeira crise de saúde mundial a poder ser compreendida em termos de globalização. ${ }^{21}$ Em tal sentido, é possível aproximar a expansão global do vírus à expansão do capitalismo, na leitura que faz Hinkelammert: como um fenômeno que se caracteriza por sua ampliação permanente, praticamente sem freios ou limites; porém, é preciso salientar, essa aproximação somente é admissível porque o vírus é conduzido, de lugar a lugar, de país a país, de continente a continente, por meio dos próprios caminhos do capitalismo global.

A rápida expansão do vírus, atingindo em algumas semanas praticamente a todas as partes do mundo, colocou governantes diante da situação de restringir severamente ou ainda proibir a circulação de pessoas, tanto externamente, entre países, quanto internamente, entre províncias e mesmo dentro das cidades, tendo como consequência a limitação e até mesmo a suspenção das atividades econômicas nos países atingidos.

Como sabemos, as respostas, tanto no âmbito sanitário, como em termos econômicos, à expansão do Covid-19 se deram de diferentes maneiras e em diversos tempos de reação, em cada país. Dessa maneira, a chegada e a identificação do vírus não configuram o único critério de retomada da normalidade - normalidade esta transformada pela continuidade de protocolos de prevenção, mesmo após o ápice do período de contaminação -; mas é condicionada, sobretudo, pelas ações realizadas por esses países.

No contexto brasileiro, a ausência de uma articulação federal das ações, estabelecendo uma diretriz nacional para o enfrentamento da crise, tem como resultado diferentes protocolos locais, a cargo, principalmente, das decisões dos governos estaduais e, em menor medida, das prefeituras.

A consequência prática disso, como se pode acompanhar nos noticiários nacionais e com destaque cada vez maior na imprensa internacional, é que o país passou a figurar, em poucas semanas, entre aqueles que contam com maior número de pessoas infectadas - mesmo sem uma política de testagem em massa, como aconteceu em outros países - e, ainda mais grave, um crescente número de vítimas fatais, sobretudo em decorrência do esgotamento da capacidade de atendimento da rede pública de saúde, em várias capitais

\footnotetext{
${ }^{20}$ Para uma primeira síntese sobre o impacto da pandemia nos diversos aspectos da vida humana, cf. PASSOS, João Décio. O vírus vira mundo. Em pequenas janelas de quarentena. São Paulo: Paulinas, 2020.

21 Cf. MALDONADO, Carlos. ¿Qué significa la crisis del Coronavirus? Informe especial. Virus biológico/virus autoritario. Le Monde diplomatique, edición 198, abril 2020, p. 4-6.
} 
do país. Mortandade que pode se revelar ainda maior, a partir do momento em que forem estabelecidos critérios que desvelem a possível subnotificação dos óbitos.

A tentativa de se preservar uma racionalidade de manutenção da atividade econômica a todo custo, inclusive ao custo de vidas humanas, sobretudo dos chamados grupos de risco, nos quais se incluem pessoas que sofrem com doenças crônicas e idosos, confronta e atenta contra a dignidade humana, implicando o que os defensores dessa posição tentam reduzir a vidas economicamente não produtivas ou pouco produtivas como baixas aceitáveis no processo de adaptação à crise mundial de saúde.

Voltemos a Mbembe: a vida que deixou de ter valor econômico, na lógica neoliberal, se tornou descartável; ao próprio Hinkelammert: para que se mantenham os lucros, para que se mantenha a acumulação econômica, o sistema capitalista aceita e deseja eliminar, sacrificar, a vida dos mais vulneráveis.

A concepção sacrificial neoliberal se faz manifestar, por exemplo, nos obstáculos colocados nas políticas públicas de auxílio, ou mesmo na recusa à assistência financeira aos trabalhadores e às famílias mais vulneráveis, assistência que se revela condição necessária para o cumprimento de medidas de isolamento social. Mais que isso, a situação de desassistência pode obrigar as populações vulneráveis a se colocar em conflito em relação a medidas de isolamento que passam a ser por elas percebidas como um obstáculo a sua subsistência, e não como uma medida efetiva de proteção à vida.

\section{Conclusão}

Visto que o capitalismo neoliberal constitui no presente o eixo a partir do qual as sociedades contemporâneas se fundamentam, não somente no campo econômico, mas nos diversos aspectos das relações sociais, sendo mesmo proposto como uma necessidade histórica - e realçamos aqui a contradição entre esses dois termos - sua crítica se faz necessária.

Neste artigo, esboçamos uma aproximação entre algumas categorias elaboradas por dois de seus principais críticos atuais: o filósofo Achille Mbembe e o teólogo e economista Franz Hinkelammert. A discussão de Mbembe sobre a africanização que caracteriza o neoliberalismo em sua etapa atual, objetificando trabalhadores e todos aqueles que não se enquadram no simbólico “1\%” que controla a riqueza mundial, mostra como a sociedade vigente reproduz, em suas relações, os mecanismos de dominação estabelecidos durante os longos séculos que chamamos de "modernidade", que tiveram 
na escravidão atlântica o seu modelo. Hinkelammert, por sua vez, explicita a lógica sacrificial, religiosa, de que o capitalismo liberal, no seu nascedouro, se apropriou, afirmando a si mesmo como um imperativo, e exigindo o sacrifício de todos e de tudo que se lhe opõem.

Acreditamos ter ao menos sugerido as potencialidades dessas duas abordagens que, embora por caminhos distintos, trazem subsídios que, a nosso ver, podem contribuir para as análises de cientistas da religião e demais pesquisadores sociais para compreender a dimensão religiosa implícita na formação e no funcionamento do mundo em que vivemos.

Explicitar os aspectos teóricos e metodológicos de uma aproximação entre Filosofia e Ciência da Religião, algo certamente necessário, ultrapassaria, no entanto, os limites propostos para este texto.

\section{Referências}

BRITO, Ênio José da Costa. Leituras afro-brasileiras, v. 1. Ressignificações afrodiaspóricas diante da condição escravizada no Brasil. Jundiaí: Paco, 2018.

DUSSEL, Enrique. 1492: o encobrimento do outro. (A origem do "mito da Modernidade"). Petrópolis, RJ: Vozes, 1993.

HINKELAMMERT, Franz. El asalto al poder mundial y la violencia sagrada del imperio. San José, Costa Rica: DEI, 2003.

MALDONADO, Carlos. ¿Qué significa la crisis del Coronavirus? Informe especial. Virus biológico/virus autoritario. Le Monde diplomatique, edición 198, abril 2020, p. 46. Disponível em: bit.ly/2TJsMYC (Acesso em 18/05/2020).

MBEMBE, Achille. Crítica da razão negra. Lisboa: Antígona, 2014.

MIGNOLO, Walter D. Colonialidade. O lado mais escuro da modernidade. Revista Brasileira de Ciências Sociais, v. 32, n. 94, junho/2017, p. 1-18.

PASSOS, João Décio. O vírus vira mundo. Em pequenas janelas de quarentena. São Paulo: Paulinas, 2020.

QUIJANO, Anibal; WALLERSTEIN, Immanuel. La americanidad como concepto, o América en el moderno sistema mundial. In: Revista Internacional de Ciencias Sociales, v. XLIV, n. 4., 1992, p. 583-594.

SAID, Edward. W. Orientalismo. O Oriente como invenção do Ocidente. São Paulo: Companhia das Letras, 2007. 
USARSKI, Frank. Constituintes da Ciência da Religião. Cinco ensaios em prol de uma disciplina autônoma. São Paulo: Paulinas, 2006.

WIRTH, Lauri Emílio. Religião e epistemologias pós-coloniais. In: PASSOS, João Décio; USARSKI, Frank. (Orgs.). Compêndio de Ciência da Religião. São Paulo: Paulinas; Paulus: 2013, p. 129-142. 